\title{
BUTORPHANOL TARTRATE: \\ 1. SAFETY AND EFFICACY IN MULTIDOSE CONTROL OF POSTOPERATIVE PAIN*
}

\author{
Allen B. Dobkin, Benjamin F. Africa, Robert J. Noveck, Frank S. Caruso, \\ Barbara Esposito, and Judith Simonds
}

The INTBAmUSCULAR ADMinistration of a single dose of butorphanol tartrate has been evaluated in double-blind comparisons with morphine and pentazocine to determine the effective dose, relative potency, and side-effects. ${ }^{1,2}$ This new compound was found to have satisfactory analgesic activity at least five times greater than morphine, 20 times greater than pentazocine, and a similar duration of effect, but without causing appreciable depression of respiration, circulation or other undesirable effects. Further evaluation, employing sequential multidoses as continued pain relief was required, was considered necessary and is the subject of this report.

\section{METHOD}

In an open study, 150 patients, who gave informed consent, were treated for post-operative severe pain in the initial 12 to 18 hours after major surgery, using intramuscular doses of 1.0, 1.5 and $2.0 \mathrm{mg}$ of butorphanol tartrate. The initial dose was based on judgement related to the size, age, and physical condition of the patient. None of those selected for treatment had a history of tolerance to pain controlling medication. Small $(55 \mathrm{~kg}$ ) or frail patients were given $1.0 \mathrm{mg}$ initially, otherwise a larger dose was given. All medicated patients were initially kept under direct surveillance by the investigators, and subsequently by trained nurses. Immediately before medication was initiated, venous blood was drawn for measurement of transaminases, bilirubin, creatinine, alkaline phosphatase and blood urea nitrogen. These tests were repeated after the analgesic medication was discontinued.

\section{RESULTS}

Table I shows the age, sex, race, and weight characteristics of the patients studied. More than 95 per cent of the patients were free of renal or hepatic disease. Most of them were in physical condition ASA II or III. None were critically ill. Eighteen patients had cancer. Premedication consisted of diazepam and atropine in more than 80 per cent of the patients. The remainder received one of pentobarbitone, hydroxyzine, meperidine, or morphine with scopolamine. Anaesthesia was induced with thiopentone $(\sim 5 \mathrm{mg} / \mathrm{kg})$ and a relaxant (pancuronium) and maintained with enflurane- $\mathrm{N}_{2} \mathrm{O}$ (90 per cent of the patients) or halothane- $\mathrm{N}_{2} \mathrm{O}$.

"From the Department of Anesthesiology, State University of New York, Upstate Medical Center, State University Hospital, Syracuse, New York, 13210, U.S.A. 
TABLE I

Vital Statistics of Patient Population (150)

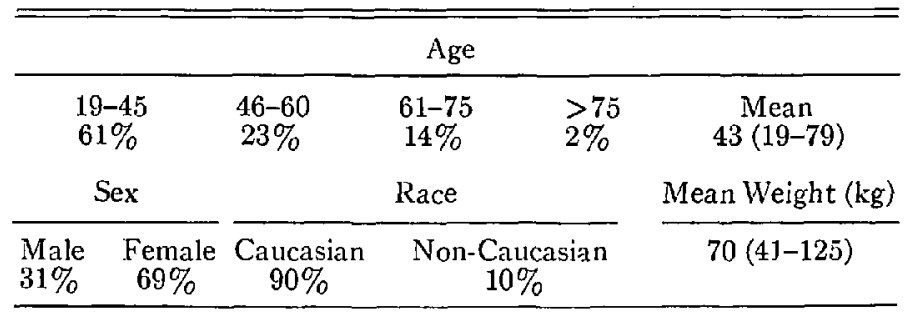

TABLE II

Distribution of Medication by Dose

\begin{tabular}{lccc}
\hline \multicolumn{2}{c}{ Doses used } & & \\
\multicolumn{1}{c}{$\mathrm{mg}$} & patients & $\begin{array}{c}\text { Total doses } \\
\text { per patient }\end{array}$ & No. patients (\%) \\
\hline 1.5 & 12 & 1 & $40(26)$ \\
2.0 & 103 & 2 & $49(33)$ \\
1.0 and 1.5 & 2 & 3 & $43(29)$ \\
1.0 and 2.0 & 1 & 4 & $14(9)$ \\
1.5 and 2.0 & 31 & 5 & $4(3)$ \\
$1.0,1.5$ and 2.0 & 1 & & \\
\hline
\end{tabular}

Most of the operations consisted of abdominal surgery (cholecystectomy, gastrectomy, bowel resection, total hysterectomy, bilateral herniorrhaphy) or total hip replacement. The patients were given atropine and neostigmine intravenously at the end of the operation if spontaneous pulmonary ventilation was inadequate. The majority of them were awake and lucid in less than 30 minutes after entering the recovery room and medication for severe pain was usually given upon request 30 to 60 minutes after arrival there. Only patients who initially complained of severe pain were admitted to the study.

Pain intensity and pain relief scores were recorded for all patients at half, one, two, three and four hours after the selected dose of butorphanol tartrate. If another dose was required, the initial pain score was resumed. Pain intensity was quantified as follows: mild $=1$, moderate $=2$, severe $=3$. Pain relief was scored: no relief $=0$, slight relief $=1$, partial relief $=2$, and complete relief $=3$. The number of patients receiving each dose and totsi2 doses per patient are shown in Table II.

A measure of efficacy was made on the basis of an estimate of the overall response of each patient to therapy with butorphanol tartrate. The results of therapy were classified as follows:

Effective: pain was relieved initially and the patient was continued on the same medication until parenteral analgesic medication was no longer required or surveillance was terminated ( $\sim 18$ hours $)$.

Partially effective: pain was relieved initially but marked pain returned too rapidly (two to three hours) and it was felt advisable to substitute alternative analgesic medication (meperidine or morphine), or the patient agreed to have a larger dose of butorphanol tartrate. 
TABLE III

EfFicacy of Butorphanol. Tartrate

\begin{tabular}{lc}
\hline \hline & Patients $(\%)$ \\
\hline $\begin{array}{lc}\text { Medication effective } \\
\text { Medication partially effective }\end{array}$ & $119(79)$ \\
Medication ineffective & $10(7)$ \\
$\quad$ analgesia obtained but & \\
refused further medication & 3 \\
analgesia denied & 1 \\
analgesia inadequate & 6 \\
refused to continue & 6 \\
\hline
\end{tabular}

TABLE IV

Pain Intensity and Pain Relief Scores After Medication in Postoperative Patients

\begin{tabular}{|c|c|c|c|c|c|c|}
\hline & \multirow{2}{*}{$\begin{array}{l}\text { Mean } \\
\text { Initial } \\
\text { Pain* }\end{array}$} & \multicolumn{5}{|c|}{$\begin{array}{c}\text { Mean } \\
\text { Pain Relief Scores } \dagger\end{array}$} \\
\hline & & $\frac{1}{2} \mathrm{hr}$ & $1 \mathrm{hr}$ & $2 \mathrm{hts}$ & 3 hrs & $4 \mathrm{hrs}$ \\
\hline $\begin{array}{l}\text { Butorphanol tartrate, } 1.0 \mathrm{mg} \\
\text { No. of patients } \\
\text { Mean } \\
\text { S.E.M. } \ddagger\end{array}$ & $\begin{array}{l}6 \\
2.92 \\
0.08\end{array}$ & $\begin{array}{l}6 \\
2.83 \\
0.17\end{array}$ & $\begin{array}{l}6 \\
2.33 \\
0.33\end{array}$ & $\begin{array}{l}5 \\
2.80 \\
0.20\end{array}$ & $\begin{array}{l}2 \\
1.00 \\
-\end{array}$ & $\begin{array}{l}2 \\
1.00 \\
-\end{array}$ \\
\hline $\begin{array}{l}\text { Butorphanol tartrate } 1.5 \mathrm{mg} \\
\text { No. of patients } \\
\text { Mean } \\
\text { S.E.M. } \neq\end{array}$ & $\begin{array}{l}62 \\
2.81 \\
0.04\end{array}$ & $\begin{array}{l}64 \\
2.61 \\
0.08\end{array}$ & $\begin{array}{l}64 \\
2.64 \\
0.06\end{array}$ & $\begin{array}{l}60 \\
2.18 \\
0.12\end{array}$ & $\begin{array}{r}41 \\
2.00 \\
0.14\end{array}$ & $\begin{array}{l}33 \\
1.76 \\
0.18\end{array}$ \\
\hline $\begin{array}{l}\text { Butorphanol tartrate } 2.0 \mathrm{mg} \\
\text { No. of patients } \\
\text { Mean } \\
\text { S.E.M. }\end{array}$ & $\begin{array}{r}270 \\
2.94 \\
0.01\end{array}$ & $\begin{array}{r}273 \\
2.42 \\
0.04\end{array}$ & $\begin{array}{r}274 \\
2.47 \\
0.04\end{array}$ & $\begin{array}{r}238 \\
2.20 \\
0.06\end{array}$ & $\begin{array}{r}176 \\
2.01 \\
0.07\end{array}$ & $\begin{array}{r}122 \\
1.80 \\
0.10\end{array}$ \\
\hline
\end{tabular}

*Mean Initial Pain Scores: $1=$ mild, $2=$ moderate, $3=$ severe.

+Mean Pain Relief Scores: $0=$ no relief, $1=$ slight relief, $2=$ moderate relief, $3=$ complete relief.

$\ddagger$ S.E.M. = Standard Error of Mean, of mean initial pain and mean pain relief scores.

Ineffective: pain was not adequately relieved with the initial medication dose and it was elected to use alternate medication within one to two hours, or the patient refused to continue with the test.

Based on these criteria, the correlation of efficacy with the causes of treatable pain are shown in Table III. It was found that butorphanol tartrate was effective or partially effective in 93 per cent of the patients, and 86 per cent of them agreed to complete the course of the study. Efficacy according to pain and pain relief scores is shown, with respect to the dose administered, in Table IV.

\section{Side-effects}

As in our double-blind studies, ${ }^{1,2}$ the only frequent side-effect observed was drowsiness ( 45 per cent of patients). All other side-effects that might be attributed to the analgesic medication were virtually absent, except for nausea in 12 per cent and vomiting in 5 per cent of the patients. Although the latter followed pain medication, the overall incidence was of an order of magnitude similar to that following inhalation anaesthesia with enflurane and halothane for abdominal operations and probably was not attributable entirely to butorphanol tartrate. ${ }^{3}$ 
Two patients may have had hallucinations related to the analgesic and/or the operation, if one considers this disturbance to be a perceptual and cognitive change in behaviour without disorientation and amnesia. These episodes were of brief duration, did not recur during the following days in hospital, and could have been due to fear of a malignancy.

None of the patients developed appreciable respiratory depression, marked changes in blood pressure, oliguria, or constipation that were related to the analgesic medication. Moderate bradycardia and miosis were observed frequently and began usually about one hour after initial medication. There were no drugrelated abnormalities in the post-operative laboratory tests that could unequivocally be related to the analgesic medication. Appreciable elevation in the SGOT occurred in several patients who underwent upper abdominal operations.

\section{COMMENT}

Butorphanol tartrate given intramuscularly in single or serial dosage, as described in this study, provided adequate relief of severe pain in more than 85 per cent of the patients studied. The overall effect appeared to be as safe as we would expect with equipotent doses of morphine or pentazocine, without an appreciable incidence of undesirable side-effects or disturbances of liver and kidney function as indicated by laboratory tests.

Most of the patients were highly pleased and accepted the new medication as an adequate substitute for meperidine, morphine and pentazocine, or other strong analgesics they have had for severe pain on previous occasions. The ten patients (of 150) who requested a change in medication undoubtedly were given an inadequate dose of butorphanol tartrate initially, since they required relatively high doses of meperidine at frequent intervals during their subsequent care, and were possibly the type of individuals with inordinately low pain thresholds, or fall into the group of 5 to 10 per cent in whom it is difficult to achieve satisfactory pain relief even with high doses of morphine. ${ }^{4}$ This inadequate response to analgesics is now felt to be due to suppression of the drug activity by rapid metabolism, or by an increase in the sensitivity to pain produced by a wide variety of drugs that patients receive in hospital, such as anticholinergics and hypnotic sedatives. ${ }^{5}$

\section{Summary and Conclusions}

Butorphanol tartrate is a potent synthetic analgesic. It was administered to 150 consenting patients with severe pain after recovery from anaesthesia. Three dose levels were used and the initial dose was based on the size and physical condition of the patient. The drug was subsequently repeated, as requested by the patients, for 12 to 18 hours following major surgery. Each patient was kept under direct surveillance by trained observers during the course of this study and the pain relief medication was evaluated for efficacy and safety. Ten patients requested a change of medication after their initial treatment, usually because pain relief was said to be inadequate, and two subjects may have developed behavioural disturbances that we related to multiple doses of butorphanol tartrate, but which could 
have been due to the fear of a lethal lesion. None of the patients developed appreciable changes in vital signs due to the analgesic.

We have concluded that this analgesic is safe and that it is as efficacious as equipotent doses of morphine and pentazocine, with a similar duration of action. It is therefore worthy of further evaluation since its propensity to causing addiction and respiratory depression is low.

\section{RÉSUMÉ}

Le tartrate de butorphanol, un puissant analgésique de synthèse, a été administré à 150 volontaires opérés pour le soulagement de douleurs importantes postanesthésie. Il fut administré en trois doses différentes, selon la taille et la condition physique des patients. La dose choisie fut répétée au besoin au cours des 12 à 18 heures suivant la chirurgie. Chaque patient était surveillé par des observateurs avertis tout au long de la présente étude, et la médication était évalulée au point de vue efficacité et sécurité. Six patients ont demandé un changement de médication après la première dose, se plaignant habituellement d'un soulagement inadéquat de la douleur. Deux patients ont développé des problèmes de comportement en relation avec des doses répétées de tartrate de butorphanol; ces problèmes auraient tout aussi bien pu être en relation avec une crainte marquée de la mort. Aucun patient n'a présenté de modifications significatives de ses signes vitaux secondaires à l'emploi de l'analgésique. Notre conclusion est la suivante : le tartrate de butorphanol est un analgésique sûr et aussi efficace que la morphine et le pentazocine à dose équivalente, avec une durée d'action comparable à ces deux agents. La faible dépression de la respiration produite et le peu de tendance à produire de l'addiction de ce médicament nous semblent justifier la poursuite de son étude.

\section{REFERENCES}

1. Dobkin, A.B., Eamkaow, S., Zak, S., \& Caruso, F.S. A double-blind evaluation in postoperative patients with moderate or severe pain. Canad. Anaesth. Soc. J. 21: 600 (1974).

2. Dobkin, A.B., Easikaow, S., \& Caruso, F.S. Butorphanol and pentazocine in patients with severe pain. Clin. Pharmacol. \& Therap. 18: 547 ( 1975).

3. Doukun, A.B., Evers, W., \& Israel, J.S. Double-blind evaluation of metoclopramide (MK745, sinimet), trimethobenzamine (tigan) and a placebo as post-anaesthetic antiemetics following methoxyflurane anaesthesia. Canad. Anaesth. Soc. J. 15: 80 (1968).

4. Keats, A.S. \& LANE, M. The symptomatic therapy of pain. Disease-A-Month, the Year Book Medical Publisher, Inc., Chicago, June 1963.

5. TAkemori, A.E. Pharmacologic factors which alter the action of narcotic analgesics and antagonists. Proc, of New York Academy of Sciences' Conference on Interactions of Drugs of Abuse, Mar. 9-11, 1976. 